\title{
ANTONIM DALAM BAHASA DAYAK RIBUN
}

\section{ANTONYM IN RIBUN LANGUAGE}

\author{
Amanah Hijriah \\ Balai Bahasa Kalimantan Barat \\ hijriah75amanah@gmail.com
}

\begin{abstract}
ABSTRAK
Bahasa Ribun merupakan salah satu bahasa yang terdapat di kabupaten Sanggau Kalimantan Barat. Tulisan ini mengkaji antonim dalam Bahasa Ribun, antonim merupakan salah satu kajian dalam semantik. Masalah dalam penelitian ini meliputi bagaimana bentuk antonim yang terdapat dalam Bahasa Ribun. Tujuan yang ingin dicapai adalah mendeskripsikan wujud antonim dalam Bahasa Ribun. Pengumpulan data menggunakan metode Simak Libat Cakap dengan teknik wawancara, catat dan rekaman.Data berupa tuturan lisan masyarakat Ribun di Desa Kedakas Kecamatan Tayan Hulu Kabupaten Sanggau, Provinsi Kalimantan Barat. Waktu pengumpulan data pada bulan Februari 2018 sampai April 2018. Selanjutnya merekam dan mendokumentasikan data dalam bentuk catatan. Setelah dikumpulkan, data bahasa dianalisis menggunakan metode agih. Kemudian, hasil analisis data bahasa tersebut disajikan dengan metode informal dan formal.Terdapat kata-kata antonim dalam bahasa Ribun yang meliputi kata sifat, kata kerja dan kata benda.
\end{abstract}

Kata kunci: antonim, bahasa, Ribun.

\begin{abstract}
Ribun language is one of the languages found in Sanggau district, West Kalimantan. This paper examines antonyms in Ribun language. Antonyms is one of the semantic studies. The problem in this study includes how the form of antonyms contained in Ribun language. The aim to be achieved is to describe the form of antonyms in Ribun Language. Data collection used the method of listening to involved with interviews, notes and recordings. Data in the form of oral speech from the Ribun community in Kedakas Village, TayanHulu District, Sanggau Regency, West Kalimantan Province. Data collection time was from February 2018 to April 2018. Furthermore, recording and documenting data in the form of notes used to collect data. After being collected, language data were analyzed using the aggregate method. Then, the results of the analysis of the language data were presented with informal and formal methods. There are antonym words in Ribun language which include adjectives, verbs and nouns.
\end{abstract}

Keywords: antonyms, language, Ribun. 


\section{PENDAHULUAN}

Provinsi Kalimantan Barat merupakan sebuah wilayah di Indonesia yang multietnik. Artinya, ada beraneka ragam etnik di dalam masyarakat yang menduduki wilayah tersebut. Berdasarkan data, setidaknya ada sepuluh etnik yang berdomisili di sana. Diketahui pula bahwa dari sepuluh etnik tadi, dua di antaranya merupakan etnik terbesar di Kalimantan Barat, yaitu Melayu sebesar 43,1\% dan Dayak sebesar 25,56\% (https://id.m.wikipedia.org). Keberagaman etnik tersebut tentunya diikuti pula oleh beragamnya bahasa. Tercatat di wikipedia pula bahwa bahasa yang dituturkan oleh masyarakat Kalimantan Barat adalah bahasa Indonesia, bahasa Melayu, Dayak, Jawa, dan Tionghoa/Mandarin.

Sebagai etnik terbesar kedua di Kalimantan Barat, Dayak terbagi lagi ke dalam beberapa subetnik, diantaranya Iban, Kanayatn, Bekatik, Golik, dan Ribun. Sub-Subetnik tersebut mendiami berbagai wilayah di Kalimantan Barat. Etnik Iban, misalnya, berdomisili di enam kabupaten, yaitu Kabupaten Kapuas Hulu, Bengkayang, Sambas, Sintang, Melawi, dan Sanggau. Etnik Kanayatn tersebar di Kabupaten Mempawah dan Landak. Etnik Bekatik tersebar di Kabupaten Sambas dan Bengkayang. Sementara itu, etnik Golik dan Ribun tersebar di Kabupten Sanggau (Alloy, dkk., 2008).

Berbicara tentang kelompok etnik dan bahasa yang ada di Kabupaten Sanggau, terdapat tiga kelompok besar di sana. Jika dikaji dari kedekatan budaya, hukum adat, dan sejarah penyebaran, suku Dayak di Kabupaten Sanggau dan Sekadau dapat dikelompokkan ke dalam tiga rumpun, yakni rumpun Dayak Bidayuh, Dayak Iban, dan Dayak Pantai. Sementara itu, berdasarkan aspek ilmu bunyi, persebaran bahasa di Kabupaten Sanggau dan Sekadau setidaknya terdapat tiga kelompok besar, yaitu kelompok Bidayuhik, Ibanik, dan Melayik. Tiga kelompok ini memiliki sub-sub yang berdomisili di daerah aliran sungai yang berbeda. Kelompok Ibanik bermukim di DAS Belitang, Sekadau, Koman, dan Mentuka'. Kemudian, kelompok Dayak Pantai bermukim di DAS Kapuas, Sekadau, Benawas, Kerabat, dan Menterap. Sementara itu, Bidayuhik sendiri merupakan kelompok terbesar jumlah penuturnya dan juga cabangnya. Penutur kelompok bahasa ini bermukim di daerah aliran sungai (DAS), Sekayam, Jangkang, Bonti, Sungai Tayan, Belitang, dan Mengkiang (Alloy, dkk., 2008: $50-51)$.

Persebaran subetnik dan penutur bahasa yang berdasarkan DAS tadi terlihatlah bahwa Ribun termasuk ke dalam kelompok Bidayuhik, Asfar (dalam Asfar, 2015: 1) mengklasifikasi bahasa Ribun yang dituturkan di kawasan Hulu Sungai Tayan sebagai salah satu varian bahasa Bidayuhik. Dayak Ribun yang dikenal juga dengan nama Hibun adalah kelompok masyarakat subsuku Dayak yang tersebar di Kecamatan Tayan Hulu, Parindu, Bonti, dan Kembayan wilayah Kabupaten Sanggau (Alloy, dkk., 2008: 130). 
Tuah Talino

Tahun XIV Volume 14 Nomor 1 Edisi 31 Juli2020

ISSN 0216-079X E-ISSN 2685-3043

Balai Bahasa Kalimantan Barat

Masyarakat Ribun menggunakan bahasa yang mereka sebut bahasa Hibun yang merupakan varian bahasa Bidayuhik. Bahasa Ribun mempunyai keunikan tersendiri, diantaranya tidak terdapat pemakaian huruf $\mathrm{R}$ pada kosa kata yang mereka gunakan.

Menurut Keraf (2004:1), bahasa adalah alat komunikasi antara anggota masyarakat berupa simbol bunyi yang dihasilkan oleh alat ucap manusia. Maksudnya, ketika anggota masyarakat menginginkan untuk komunikasi dengan sesamanya, orang tersebut akan mengunakan suatu bahasa yang sudah biasa di gunakannya untuk menyampaikan sesuatu informasi. Pada umumnya, bahasabahasa tersebut dapat berbeda antara satu daerah dengan daerah yang lain. Hal ini dikarenakan adanya perbedaan kultur, lingkungan, dan kebiasaan yang mereka miliki. Bahasa daerah merupakan sebuah identitas dan kekayaan suatu kelompok masyarakat yang dijadikan sebagai alat tutur dalam berkomunikasi dengan sekelompok masyarakat. Ada ungkapan "Bahasa menunjukan bangsa" berarti tutur kata seseorang akan menunjukan bagaimana sifat dan watak orang itu.

Penelitian bahasa daerah yang tersebar di seluruh daerah yang ada di Indonesia merupakan upaya melestarikan bahasa daerah yang ada di Indonesia. Berdasarkan kenyataan yang dikemukakan di atas, peneliti merasa terpanggil untuk mengkaji dan mengangkat penelitian bahasa pada masyarakat Ribun. Antonim pada bahasa Ribun cukup menarik untuk diteliti karena disamping mengenal bentuk kata berantonim dalam bahasa Ribun, juga mengenal sejumlah bentuk antonim bahasa Ribun.

Masalah pokok penelitian ini yaitu bagaimanakah deskripsi bentuk-bentuk antonim berdasarkan sifatnya dalam bahasa Ribun. Tujuan yang akan dicapai dalam penelitian ini adalah untuk mendeskripsikan bentuk-bentuk antonim berdasarkan sifatnya dalam bahasa Ribun. Antonim merupakan bagian dari semantik. Manfaat penelitian ini secara teoretis, diharapkan dapat menjadi bahan masukan ataupun tambahan referensi yang berkaitan dengan satuan-satuan dasar bahasa, khususnya bahasa daerah, serta untuk meningkatkan pengetahuan dan penguasaan kosa kata pemakian bahasa Ribun dalam upaya pembinaan dan pengembangannya. Sementara itu, dari sisi praktis, kajian ini diharapkan dapat menjadi referensi bagi peneliti, pengkaji, ataupun pemerhati bahasa Ribun sekaligus dapat menjadi cara untuk lebih mengenal etnik Ribun-dari sisi bahasa tentunya.

Penelitian tentang bahasa Ribun secara umum sudah pernah dilakukan. Asfar (2015), melalui hasil penelitiannya yang berjudul Bahasa Ribun: Refleks Fonem Proto-Melayu Polinesia. Irmayani, dkk. (2018) Mengkaji Fonologi Bahasa Ribun. Novianti, dkk. (2018). Morfologi Bahasa Ribun. Penelitian ini mendeskripsikan struktur morfologi Bahasa Ribun. Duantika, dkk. (2018). Sintaksis Bahasa Ribun. Penelitian ini mendeskripsikan struktur kalimat dalam 
Tuah Talino

Tahun XIV Volume 14 Nomor 1 Edisi 31 Juli2020

ISSN 0216-079X E-ISSN 2685-3043

Balai Bahasa Kalimantan Barat

Bahasa Ribun. Beberapa penelitian yang ada tidak membahas tentang antonim dengan kelas katanya masing-masing, peneliti tertarik untuk mengangkat permasalahan antonim dalam bahasa Ribun dengan kelas katanya.

Semantik adalah telaah terhadap lambang-lambang atau tanda-tanda menyatakan makna, hubungan makna yang satu dengan yang lain dan pengaruhnya terhadap manusia dan masyarakat termasuk perkembangan dan perubahannya (Tarigan, 1990:166). Sejalan dengan Tarigan, Kridalaksana (2008:216) menyatakan semantik adalah bagian struktur bahasa yang berhubungan dengan makna ungkapan dan juga dengan struktur makna suatu wicara.Semantik adalah salah satu tataran dalam analisis bahasa yang hanya berhubungan dengan makna dalam bahasa verbal. Makna ini terdapat dalam ujaran seperti kata, frase, klausa, dan kalimat. Makna akan diketahui jika menghubugkan antara kata atau simbol dengan konsep atau referensi dan hal yang diacu oleh makna tersebut. Salah satu pokok bahasan tersebut adalah antonim. (Yayuk,R. 2017:299). Dalam bahasa Ribun, ditemui adanya hubungan kemaknaan atau relasi semantik antara sebuah kata atau satuan bahasa lainnya, dibahas dalam tulisan ini hanyalah relasi pertentangan kata (antonim) sesuai dengan masalah pokok dalam penelitian.

Kata antonim berasal dari kata Yunani kuno, yaitu anoma yang artinya nama dan anti yang artinya melawan, secara harfiah antonim berarti nama lain atau benda lain. Secara semantik, Tarigan (1990:36) mendefenisikan sebagai kata yang mengandung makna yang berkebalikan atau berlawanan.

Darmojuwono (2005:118) menyatakan antonimi atau oposisi adalah relasi antarkata yang bertentangan atau berkebalikan maknanya. Dalam antonimi digunakan istilah oposisi makna dalam pasangan leksikal bertaraf, seperti panas dengan dingin, antonim ini disebut bertaraf karena antara panas dan dingin masih ada kata-kata lain seperti hangat dan suam-suam kuku. Oposisi makna dalam pasangan leksikal tidak bertaraf yang maknanya bertentangan disebut oposisi komplementer, seperti jantan dengan betina.

Antonim adalah perlawanan makna, misalnya kata terang dan gelap. Kalimat atau kata-kata yang berantonim saling berkontradiksi satu sama lainnya (Wijana, 2015:55), selanjutnya Wijana juga menyatakan pasangan kata antonim yang mencakup pada kelas kata kata sifat, kata kerja dan kata benda. Antonim merupakan bagian dari kajian semantik, yang membahas tentang kontradiksi suatu kalimat atau kata-kata, kajian ini membahas antonim kata yang mencakup kelas kata yang dimaksudkan (2015: 55-60).

Nakhrawie (2008:5-22) menyatakan kata sifat adalah kata yang menyatakan sifat atau hal keadaan dari suatu benda atau sesuatu yang dahului kata lebih, agak, paling, sangat, dan cukup. Kata kerja yaitu kata yang menyatakan perbuatan atau laku, cirinya dapat diperluas dengan kata sedang dan mendapat imbuhan me-. 
Selanjutnya kata benda yang dapat diperluas dengan menambah kata yang dan kata sifat atau dapat disanding dengan kata negasi bukan.

\section{METODE}

Penelitian ini merupakan penelitian kualitatif dengan menggunakan metode deskriptif. Faizah (2009:72) mengemukakan bahwa metode deskriptif yaitu dengan penggambaran atau pelukisan keadaan subjek atau objek penelitian berdasarkan fakta atau fenomena yang ada. Penelitian kualitatif adalah prosedur penelitian yang menghasilkan data deskriptif berupa kata-kata tertulis atau lisan tentang orang-orang dan perilaku yang diamati (Moleong, 2002:4).

Pengumpulkan data menggunakan metode Simak Libat Cakap dengan teknik wawancara, catat dan rekaman. Peneliti menyimak tuturan lisan masyarakat Ribun di Desa Kedakas, Kecamatan Tayan Hulu, Kabupaten Sanggau, Provinsi Kalimantan Barat. Pengumpulan data pada bulan Februari 2018 sampai April 2018. Selanjutnya merekam dan mendokumentasikan dalam bentuk catatan. Setelah dikumpulkan, data bahasa dianalisis menggunakan metode agih karena bahasa tersebut tanpa menghubungkannya dengan hal-hal di luar bahasa (Sudaryanto, 2015). Kemudian, hasil analisis data bahasa tersebut disajikan dengan metode informal dan formal. Dapat dikatakan demikian karena data tadi disajikan dengan kata-kata biasa, tanda dan lambang dalam pemaparan hasil analisisnya.

\section{PEMBAHASAN}

Hasil penelitan kata antonim dalam bahasa Ribun memiliki kelas kata sifat, kata kerja, dan kata benda. Berikut contoh kata antonim dalam bahasa Ribun.

\section{Kelas Kata Sifat}

Kata sifat adalah kata yang menyatakan sifat atau hal keadaan dari suatu benda atau sesuatu yang dahului kata lebih, agak, paling, sangat, dan cukup. (Nakhrawie, 2008:5-22)

Data [1]

Cik obiankng rezeki dek nti nopak di syukuri

'sedikit banyak rezeki yang kita dapat harus disyukuri'

Data [2]

Yok nyomok dankng ha, sebiho atau busoh odia menghaguak omu

'jangan mendekati hewan itu, lapar atau kenyang ia akan mencakarmu' 
Data [3]

Simok ojek, ojau somok mayiah tetap sehupo

'naik ojek, jauh dekat bayarannya tetap sama'

Data [4]

Mioh awoh nyok ako, domuah atau dik terserah omo

'ambilakan aku bambu, panjang atau pendek terserah kamu'

Data [5]

Odia ha tetap behongkak ngkai peduli onu ta'hang atau pitu

'dia akan tetap pergi tidak peduli hari terang atau gelap'

Data [1], [2], [3], [4], dan [5] terdapat antonim yang memiliki kelas kata sifat. Pasangan antonimCik obiank'ng 'sedikit banyak' dalam kalimat data 1, cik obiank'ng rezeki dek nti nopak di syukuri 'sedikit banyak rezeki yang kita dapat harus disyukuri'. Kata cik 'sedikit' berantonim dengan kataobiank'ng 'banyak'. Pasangan antonim sebiho busoh lapar kenyang yang a pada kalimat di data [2] yok nyomok dankng ha, sebiho atau busoh odia menghaguak omu yang bermakna jangan mendekati hewan itu, lapar atau kenyang ia akan mencakarmu. Kata sebiho 'lapar' berantonim dengan kata busoh 'kenyang'. Berikutnya, pasangan antonim ojau somokla'jauh dekat' yang terdapat pada data [3] dalam kalimat simok ojek, ojau somok mayiah tetap sehupo yang memiliki arti 'naik ojek, jauh dekat bayarannya tetap sama'. Kata ojaw 'jauh' berantonim dengan kata sehupo 'dekat'. Padadata [4] terdapat pasangan antonim domuah dik'panjang pendek' yang terdapat dalam kalimat pada data [4] mioh awoh nyok ako, domuah atau dikterserah omo yang bermakna ambilakan aku bambu, panjang atau pendek terserah kamu. Kata domuah 'panjang' berantonim dengan kata dik 'pendek'. Pasangan antonim kelas kata sifat terdapat pada kata ta'hang pitu 'terang gelap' dapat dilihat pada kalimat data [5] odiak ha tetap behongkak ngkai peduli onu ta'hang atau pitu 'dia akan tetap pergi tidak peduli hari terang atau gelap'. Kata ta'hang 'terang' berantonim (berlawanan) dengan kata pitu 'gelap'.

Pasangan-pasangan kata antonim dalam kelima data tersebut, merupakan kata sifat yang sesuai dengan apa yang dinyatakan Wijana (2015;55-60) salah satu kelas kata antonim adalah pasangan kata antonim beranggotakan kelas kata sifat.

\section{Kata Kerja}

Menurut Nakhrawie (2008:5-22) Kata kerja yaitu kata yang menyatakan perbuatan atau laku, cirinya dapat diperluas dengan kata sedang dan mendapat imbuhan me- (Nakhrawie, 2008:5-22).

Data [6]

Dimo? mise ${ }^{y}$ ? mi:mo? naw ?

'kalian bertanya kami menjawab' 
Data [ 7]

Sungguh jeh muntuh, abai ha bahayiak kawe'nt becahok

'walaupun sudah tua, kakek itu sering kawin cerai'

Data [8]

Kepala Dusun jeh baso mohi onu kone negeri sebalah

'kepala dusun sudah biasa pulang pergi ke negeri sebelah'

Data [9]

Kehijo pak nyua mihis baha'ng biak

'pekerjaan ayahnya jual beli barang bekas'

Data [10]

Tuluəy kumo? tayka? koyo" haysimok temonow

'tolong kamu angkat barang itu naik turun'

Data [6], [7], [8], [9], dan [10] menggunakan antonim yang memiliki kelas kata kerja. Pasangan antonim ini yaitu misey ${ }^{y}$ naw ${ }^{2}$ ' bertanya menjawab' kata tersebut terdapat pada kalimat [6] dimo? mise ${ }^{y}$ ? mi:mo? naw ${ }^{\curvearrowright}$ ? yang bermakna kalian bertanya kami menjawab. Kata mise ${ }^{y}$ ? 'bertanya' bersinonim dengan kata naw ${ }^{2}$ ? 'menjawab'. Pasangan antonim kawe'nt becahok 'kawin cerai', pada kalimat [7] sungguh jeh muntuh, abai ha bahayiak kawe'nt becahok yang berarti walaupun sudah tua, kakek itu sering kawin cerai'. Kata kawe'nt 'kawin' bersinonim dengan kata becahok 'bercerai'. Selanjutnya pada kata mohi kone 'pulang pergi' yang terdapat pada kalimat pada data [8] kepala dusun jeh baso mohi onu kone negeri sebalah yang maknanya kepala dusun sudah biasa pulang pergi ke negeri sebelah. Kata mohi 'pulang' berantonim dengan kata kone 'pergi'. Pasangan antonim nyua mihis 'jual beli' pada kalimat di data [9] kehijo pak nyua mihis baha'ng biak yang bermakna pekerjaan ayahnya jual beli barang bekas. Kata nyua 'jual' berantonim dengan kata mihis 'beli'. Pasangan terakhir pada kelas kata kerja yaitu simok temonow 'naik turun' yang terdapat pada data [10] kalimatnya tuluəy kumo? tayka? koyo " hay simok temonow yang artinya tolong kamu angkat barang itu naik turun. Kata simok 'naik' berantonim dengan kata temonow 'turun'.

\section{Kata Benda}

Kata benda yang dapat diperluas dengan menambah kata yang dan kata sifat atau dapat disanding dengan kata negasi bukan.

Data [11]

Nyowo ngohit'n ngakai nogok ujan't dalam ming'gu nto

'siang malam tidak berhenti hujan dalam minggu ini' 
Data [12]

Pak mak ako kehijo nti negeri Jiran

'ayah ibu ku bekerja di negeri Jiran'

Data [13]

Nahi atau dayung sehupo maih, dek penting onok sade sehat

'lelaki atau perempuan sama saja, yang penting bayinya sehat'

Data [14]

Ohut ha bejala'nt sik sobo kene saju

'perahu itu berlayar dari hilir ke hulu'

Data [15]

Tiap ngohi'nt Minggu, hayak ompuk behongkak kone kuta ngkai peduli muntuh mongut

'setiap malam Minggu, penduduk desa pergi ke kota tak peduli tua atau muda'

Data [11[, [12], [13], [14], dan [15] menggunakan data pasangan kata antonim yang berasal dari kata benda. Pasangan antonim tersebut adalah kata Nyowo ngohit 'siang malam' yang terdapat dalam kalimat pada data [11] Nyowo ngohit'n ngakai nogok ujan't dalam ming'gu nto yang bermakna siang malam tidak berhenti hujan dalam minggu ini. Kata Nyowo 'siang' berantonim dengan kata ngohit 'malam'. Pasangan kata antonim lainnya terdapat pada kata Pak Mak 'bapak ibu' terdapat pada kalimat data [12] Pak mak ako kehijo nti negeri Jiran yang bermakna 'ayah ibuku bekerja di negeri Jiran'. Kata Pak 'bapak' berantonim dengan kata mak' ibu'. Selanjutnya pada data [13] terdapat pasangan antonim pada kata nahi dayung 'laki-laki perempuan' yang terdapat dalam kalimat Nahi atau dayung sehupo maih, dek penting onok sade sehat yang bermakna lelaki atau perempuan sama saja, yang penting bayinya sehat'. Kata nahi 'laki-laki' berantonim dengan dayung 'perempuan'. Pasangan antonim selanjutnya kata sobo saju 'hilir hulu' dapat diketahui dari kalimat pada data [14] Ohut ha bejala'nt sik sobo kene saju yang berarti perahu itu berlayar dari hilir ke hulu. Kata sobo 'hilir' berantonim dengan kata saju 'hulu'. Pasangan antonim lainnya yaitu kata muntuh mongut 'tua muda', terdapat pada data [15] tiap ngohi'nt Minggu, hayak ompuk behongkak kone kuta ngkai peduli muntuh mongut yang bermakna 'setiap malam Minggu, penduduk desa pergi ke kota tak peduli tua atau muda'. Kata muntuh 'tua' berantonim dengan kata mongut 'muda. 


\section{PENUTUP}

Hasil kajian yang telah dipaparkan, dapat diketahui keantoniman dalam bahasa Ribun yang dituturkan secara lisan masyarakat di desa Kedakas Kecamatan Tayan Hulu Kabupaten Sanggau Kalimantan Barat dalam hal ini keantoniman kata yang meliputi kata sifat, kata kerja, dan kata benda.

Antonim kata sifat dapat terlihat pada kata Cik obiankng 'sedikit banyak', sebih-busoh 'lapar-kenyang', ojau somok 'jauh-dekat', domuah-dik 'panjangpendek', ta'hang-pitu 'terang-gelap'.

Antonim kata kerja dapat kita ketahui pada kata misey naw $^{\curvearrowright}$ ? bertanya menjawab', kawe'nt becahok 'kawin cerai', mohi kone 'pulang pergi', nyua mihis 'jual beli', simok temonow 'naik turun'.

Selanjutnya Antonim pada kata benda terdapat pada kata nyowo ngohit 'siang malam', Pak mak 'bapak ibu', nahi dayung 'laki-laki perempuan', sobo saju 'hilir hulu', dan muntuh mongut 'tua muda'.

Kajian keantoniman dalam bahasa Ribun ini melengkapi beberapa kajian terdahulu yang pernah dilakukan beberapa peneliti bahasa Ribun. Diharapkan kajian-kajian yang pernah ada tersebut dapat dijadikan salah satu upaya pemertahanan bahasa Ribun. Kedepannya kajian kajian tersebut bisa dijadikan pelengkap dalam sumber pembelajaran materi muatan lokal di Kalimantan Barat khusunya di Kabupaten Sanggau. Pembelajaran muatan lokal khususnya bahasa daerah merupakan upaya pemerintah dalam merevitalisasi bahasa daerah yang ada di Indonesia khususnya di Kalimantan Barat.

\section{DAFTAR PUSTAKA}

Alloy, dkk. (2008) Mozaik Dayak: Keberagaman Subsuku dan Bahasa Dayak di Kalimantan Barat. Pontianak: Institut Dayakologi.

Asfar, Dedy Ari. (2015) Bahasa Ribun: Refleks Fonem Proto-Melayu Polinesia dalam Bahasa Ribun. Pontianak: Top Indonesia.

Darmojuwono, Setiawati. (2005) "Semantik". Dalam Pesona Bahasa: Langkah Awal Memahami Linguistik. Penyunting: Kushartanti, Untung Yuwono, dan Multamia RMT Lauder. Jakarta: Gramedia Pustaka Utama.

Duantika, dkk. (2018) Sintaksis Bahasa Ribun. Balai Bahasa Kalimantan Barat. Faizah, Hasanah. (2009) Menulis Karangan Ilmiah. Pekanbaru: Cendikia Insani. Irmayani, dkk. (2018) Fonologi Bahasa Ribun. Balai Bahasa Kalimantan Barat. Keraf, G. (2004) Diksi dan Gaya Bahasa. Ende: Nusa Inda.

Kridalaksana, Harimurti. (1994) Kelas Kata dalam Bahasa Indonesia. Jakarta: PT Gramedia.

Moleong, Lexy J. (2002) Metodologi Penelitian Kuantitatif. Bandung: Rosda Nakhrawie An Asrifin. (2008) Intisari Bahasa Sastra Indonesia. Agung Media Mulia. 
Tuah Talino

Tahun XIV Volume 14 Nomor 1 Edisi 31 Juli2020

ISSN 0216-079X E-ISSN 2685-3043

Balai Bahasa Kalimantan Barat

Novianti, dkk. (2018). Morfologi Bahasa Ribun. Balai Bahasa Kalimantan Barat.

Sudaryanto. (2015). Metode dan Teknik Analisis Bahasa: Pengantar Penelitian

Wahana Kebudayaan secara Linguistis. Yogyakarta: Sanata Dharma University Press.

Tarigan, Guntur Hendri. (1990). Pengantar Semantik. Bandung: Angkasa.

Wijayana, I Dewa Putu. (2015). Pengajaran Semantik. Yogyakarta: Pustaka Pelajar.

Yayuk,Risari. (2017). Kelas Kata Antonim Dalam Bahasa Banjar. Jurnal Telaga Bahasa Volume 5, Nomor 2, Desember 2017. Kantor Bahasa Gorontalo. https://id.m.wikipedia.org. 